\title{
Functional Specificity of $\mathrm{G} \alpha_{\mathrm{g}}$ and $\mathrm{G} \alpha_{11}$ in the Cholinergic and Glutamatergic Modulation of Potassium Currents and Excitability in Hippocampal Neurons
}

\author{
Michael Krause, ${ }^{1}$ Stefan Offermanns, ${ }^{2}$ Martin Stocker, ${ }^{1,3}$ and Paola Pedarzani ${ }^{1,4}$ \\ ${ }^{1}$ Max-Planck-Institute for Experimental Medicine, Department of Molecular Biology of Neuronal Signals, 37075 Göttingen, \\ Germany, 2Institute of Pharmacology, University of Heidelberg, 69120 Heidelberg, Germany, and 3Wellcome Laboratory \\ for Molecular Pharmacology, Department of Pharmacology, and ${ }^{4}$ Department of Physiology, University College London, \\ London WC1E 6BT, United Kingdom
}

In hippocampal and other cortical neurons, action potentials are followed by a slow afterhyperpolarization (sAHP) generated by the activation of small-conductance $\mathrm{Ca}^{2+}$-activated $\mathrm{K}^{+}$ channels and controlling spike frequency adaptation. The corresponding current, the apamin-insensitive $s l_{\mathrm{AHP}}$, is a well known target of modulation by different neurotransmitters, including acetylcholine (via $\mathrm{M}_{3}$ receptors) and glutamate (via metabotropic glutamate receptor $5, \mathrm{mGluR}_{5}$ ), in CA1 pyramidal neurons. The actions of muscarinic and mGluR agonists on $\mathrm{Sl}_{\mathrm{AHP}}$ involve the activation of pertussis toxin-insensitive G-proteins. However, the pharmacological tools available so far did not permit the identification of the specific G-protein subtypes transducing the effects of $\mathrm{M}_{3}$ and $\mathrm{mGluR}_{5}$ on $\mathrm{s}_{\mathrm{AHP}}$. In the present study, we used mice deficient in the $\mathrm{G} \alpha_{\mathrm{q}}$ and $\mathrm{G} \alpha_{11}$ genes to investigate the specific role of these G-protein $\alpha$ subunits in the cholinergic and glutamatergic modulation of $\mathrm{s} /_{\mathrm{AHP}}$ in CA1 neurons. In mice lacking $\mathrm{G} \alpha_{\mathrm{q}}$, the effects of muscarinic and glutamatergic agonists on $\mathrm{sl}_{\mathrm{AHP}}$ were nearly abolished, whereas $\beta$-adrenergic agonists acting via $\mathrm{G} \alpha_{\mathrm{s}}$ were still fully effective. Modulation of $\mathrm{sl}_{\mathrm{AHP}}$ by any of these agonists was instead unchanged in mice lacking $\mathrm{G} \alpha_{11}$. The additional depolarizing effects of muscarinic and glutamatergic agonists on CA1 neurons were preserved in mice lacking $\mathrm{G} \alpha_{\mathrm{q}}$ or $\mathrm{G} \alpha_{11}$. Thus, $\mathrm{G} \alpha_{\mathrm{q}}$, but not $\mathrm{G} \alpha_{11}$, mediates specifically the action of cholinergic and glutamatergic agonists on $\mathrm{s}_{\mathrm{AHP}}$, without affecting the modulation of other currents. These results provide to our knowledge one of the first examples of the functional specificity of $\mathrm{G} \alpha_{\mathrm{q}}$ and $\mathrm{G} \alpha_{11}$ in central neurons.

Key words: G-protein; muscarinic; metabotropic glutamate; calcium-activated potassium current; afterhyperpolarization; CA1 pyramidal neurons
In the hippocampus, glutamatergic and cholinergic regulation of neuronal excitability is thought to play a pivotal role in learning and memory processes (Pin and Bockaert, 1995; Riedel, 1996; Segal and Auerbach, 1997; Holscher et al., 1999; Perry et al., 1999). Acetylcholine and glutamate, beside mediating fast excitatory synaptic transmission in the CNS, modulate neuronal metabolic responses by acting on metabotropic receptors (muscarinic and metabotropic glutamate receptors, mGluRs). Previous studies have focussed on the molecular and cellular mechanisms by which muscarinic and mGluR agonists regulate membrane excitability in central and peripheral neurons and have revealed their effects on several ionic currents, such as the following: (1) the M current $\left(I_{\mathrm{M}}\right)$, a voltage-dependent $\mathrm{K}^{+}$current (Brown and Adams, 1980; Halliwell and Adams, 1982); (2) a voltage-independent "leak" $\mathrm{K}^{+}$current $\left[I_{\mathrm{K}(\text { leak })}\right]$ (Madison et al., 1987; McCormick and von Krosigk, 1992; Guerineau et al., 1994); (3) the slowly

\footnotetext{
Received May 31, 2001; revised Oct. 9, 2001; accepted Nov. 6, 2001.

This work was supported by Deutsche Forschungsgemeinschaft Sonderforschungsbereich 406 (M.S., P.P.), the Human Frontier Science Program (P.P.), and the Wellcome Trust (M.S.). We are very grateful to Walter Stühmer for generous support. We thank David A. Brown for useful discussion and critical reading of this manuscript and Christina Sterner and the personnel of the transgenic animal facility of the Max-Planck-Institute for Experimental Medicine for technical assistance.

Correspondence should be addressed to Dr. Paola Pedarzani, Department of Physiology, University College London, Gower Street, London WC1E 6BT, UK. E-mail: p.pedarzani@ucl.ac.uk.

M. Krause's present address: Pharmacia Corporation, Neurobiology, 301 Henrietta Street, Kalamazoo, MI 49007.

Copyright (ㄷ) 2002 Society for Neuroscience $\quad 0270-6474 / 02 / 220666-08 \$ 15.00 / 0$
}

inactivating $\mathrm{K}^{+}$current $I_{\mathrm{D}}$ (Wu and Barish, 1999); (4) the delayed rectifier $\mathrm{K}^{+}$current $I_{\mathrm{K}}$ (Zhang et al., 1992); (5) the unspecific cationic pacemaker current $\left(I_{\mathrm{h}}\right)$ (Colino and Halliwell, 1993); (6) a $\mathrm{Ca}^{2+}$-dependent, cation-nonspecific current (Crepel et al., 1994; Greene et al., 1994; Guerineau et al., 1995; Haj-Dahmane and Andrade, 1997, 1999); and (7) the $\mathrm{Ca}^{2+}$-activated $\mathrm{K}^{+}$current responsible for the slow afterhyperpolarization $\left(\mathrm{sI}_{\mathrm{AHP}}\right)(\mathrm{Be}-$ nardo and Prince, 1982; Cole and Nicoll, 1983, 1984; Charpak et al., 1990).

The signal transduction pathways mediating these muscarinic and mGluR effects are only partly understood in hippocampal as in other central neurons. In particular, the involvement and molecular identification of G-proteins has been carefully investigated in some peripheral (Hille, 1994; Brown et al., 1997), but not in central neurons. Pertussis toxin-insensitive G-proteins have been proposed to be involved in the suppression of $I_{\mathrm{M}}, \mathrm{s} I_{\mathrm{AHP}}$, and $I_{\mathrm{K}(\mathrm{leak})}$ by muscarinic agonists in CA1 neurons (Dutar and Nicoll, 1988). However, the lack of selective pharmacological tools and the difficulty of successfully applying antisense or antibody techniques, as in dissociated or cultured cells (McFadzean et al., 1994; Ikeda, 1997; Buckley et al., 2000), has so far prevented the identification of specific G-protein subtypes mediating cholinergic and glutamatergic actions in central neurons in situ. Their identification is important, because the diversity of G-protein forms is likely to be matched by a corresponding range of cellular targets and functions.

The high structural homology, overlapping distribution pat- 
terns, and similar coupling properties to downstream effectors of $\mathrm{G} \alpha_{\mathrm{q}}$ and $\mathrm{G} \alpha_{11}$ subunits (Wu et al., 1992; Offermanns et al., 1994; Exton, 1996; Offermanns, 1999) have raised the question of their functional specificity in physiological systems. In this study, we unequivocally identified the G-protein subtypes that selectively transduce the signals of muscarinic $\mathrm{M}_{3}$ and glutamatergic $\mathrm{mGluR}_{5}$ receptors on $\mathrm{s} I_{\mathrm{AHP}}$ in CA1 pyramidal neurons in mouse hippocampal slices. Using knock-out mice lacking $\mathrm{G} \alpha_{\mathrm{q}}$ or $\mathrm{G} \alpha_{11}$ subunits, we showed that $\mathrm{G} \alpha_{\mathrm{q}}$, but not $\mathrm{G} \alpha_{11}$, mediates the downregulation of $\mathrm{s} I_{\mathrm{AHP}}$ by both muscarinic and $\mathrm{mGluR}$ agonists. Neither $\mathrm{G} \alpha_{\mathrm{q}}$ nor $\mathrm{G} \alpha_{11}$ seem instead to be required for the slow depolarization induced by these agonists. This study provides, to our knowledge, the first evidence of precise and distinct roles of these two G-protein $\alpha$ subunit isoforms in physiologically relevant signaling pathways in central neurons.

\section{MATERIALS AND METHODS}

$G \alpha_{q}$-and $G \alpha_{11}$-deficient mice. Mice deficient in the $\mathrm{G} \alpha_{\mathrm{q}}$ gene $\left(\mathrm{G} \alpha_{\mathrm{q}}-/-\right)$ or the $\mathrm{G} \alpha_{11}$ gene $\left(\mathrm{G} \alpha_{11}-/-\right)$ were generated by targeted disruption with a neomycin gene as described previously (Offermanns et al., 1997, 1998). $\mathrm{G} \alpha_{\mathrm{q}}-/-$ and $\mathrm{G} \alpha_{11}-/-$ mice used in the experiments were obtained by mating heterozygous males and females to obtain wild-type $\left(\mathrm{G} \alpha_{\mathrm{q}}+/+\right.$; $\left.\mathrm{G} \alpha_{11}+/+\right)$ and knock-out $\left(\mathrm{G} \alpha_{\mathrm{q}}-/-; \mathrm{G} \alpha_{11}-/-\right)$ littermates. Mice were kept on a C57BL/ $6 \times 129 / \mathrm{Sv}$ background, and genotypes were confirmed by PCR on genomic DNA from tail biopsies of each mouse. All experiments were performed in a double-blind manner, and the code was broken only after completion of the experimental work and data analysis.

Slice preparation. Acute slices were obtained from Wistar rats (18-28 d old), $\mathrm{G} \alpha_{\mathrm{q}}-/-$ mice (11-24 weeks old), $\mathrm{G} \alpha_{11}-/-$ mice (14-25 weeks old), or wild-type mice. Wild-type mice were NMRI albino mice (4-8 weeks old), C57BL/6J (8-12 weeks old) mice, or littermates of $\mathrm{G} \alpha_{\mathrm{q}}-/-$ or $\mathrm{G} \alpha_{11}-/-(11-25$ weeks old $)$. Throughout the text, it is specified to which group we refer according to the experiment performed. Transversal hippocampal slices $(300-400 \mu \mathrm{m})$ were cut with either a tissue chopper (Mickle Laboratory, Gomshall, Surrey, UK) or a vibratome (Leica, Nussloch, Germany) and subsequently incubated in a humidified interface chamber at room temperature for $\geq 1 \mathrm{hr}$.

Electrophysiology. Tight-seal whole-cell voltage-clamp recordings were obtained using the "blind method" (Blanton et al., 1989). Patch electrodes (4-7 M $\Omega$ ) were filled with an intracellular solution containing (in $\mathrm{mM}$ ): 140 potassium methylsulfate, $10 \mathrm{HEPES}, 2 \mathrm{Na}_{2}$-ATP, $0.4 \mathrm{Na}_{3}$-GTP, and $3 \mathrm{MgCl}_{2}$ (osmolarity, 280-300 mOsm), $\mathrm{pH}$ 7.2-7.3 with $\mathrm{KOH}$. Recordings were performed in a submerged recording chamber with a constant flow of artificial CSF (ACSF) $(2 \mathrm{ml} / \mathrm{min}$ ) at room temperature $\left(22-24^{\circ} \mathrm{C}\right)$. Drugs were applied in the bath solution. ACSF contained (in $\mathrm{mm}$ ): $125 \mathrm{NaCl}, 1.25 \mathrm{KCl}, 2.5 \mathrm{CaCl}_{2}, 1.5 \mathrm{MgCl}_{2}, 1.25 \mathrm{KH}_{2} \mathrm{PO}_{4}, 25$ $\mathrm{NaHCO}_{3}$, and 16 D-glucose [bubbled with carbogen $\left(95 \% \mathrm{O}_{2}-5 \% \mathrm{CO}_{2}\right.$ ]. In all recordings, tetrodotoxin (TTX) $(0.5 \mu \mathrm{M})$, tetraethylammonium (TEA) $(5 \mathrm{mM})$, and picrotoxin $(5 \mu \mathrm{M})$ were added to the superfusing ACSF. Whole-cell patch-clamp recordings were obtained from 90 neurons from mice and 13 from rats in acute hippocampal slices. Neurons were voltage clamped at $-60 \mathrm{mV}$, and 100- to 200-msec-long depolarizing pulses to $0-30 \mathrm{mV}$ were delivered every $30 \mathrm{sec}$. These pulses led to unclamped $\mathrm{Ca}^{2+}$ action currents sufficient to activate AHP currents. Slow depolarizing currents were measured as changes in the holding current under the same experimental conditions (same intracellular and extracellular solutions; holding potential of $-60 \mathrm{mV}$ ). Series resistance was regularly monitored, and only recordings with stable series resistances $\leq 35 \mathrm{M} \Omega$ were included in this study. No series resistance compensation and no corrections for liquid junction potentials were made. Data were acquired using a patch-clamp EPC9 amplifier (Heka Elektronik, Lambrecht/Pfalz, Germany), filtered with a $-3 \mathrm{~dB}$ cutoff frequency at $250 \mathrm{~Hz}$, sampled at $1 \mathrm{KHz}$, and stored on a Macintosh Power personal computer (Apple Computers, Cupertino, CA). Analysis was made using the programs Pulse and Pulsefit (Heka), Igor Pro 3.01 (WaveMetrics Inc., Lake Oswego, OR), and Excel (Microsoft, Seattle, WA). We analyzed the amplitude, charge transfer (area enclosed by $I_{\mathrm{AHP}}$ and $\mathrm{s} I_{\mathrm{AHP}}$ ), and time course of AHP currents decay. No discrepancies in the variations of these parameters on pharmacological manipulations were observed; therefore, in Results and the figures, we reported only the values concerning $I_{\mathrm{AHP}}$ and $\mathrm{s} I_{\mathrm{AHP}}$ amplitudes. The amplitude of $I_{\mathrm{AHP}}$ was determined at the peak of the current, whereas that of $\mathrm{s} I_{\mathrm{AHP}}$ was
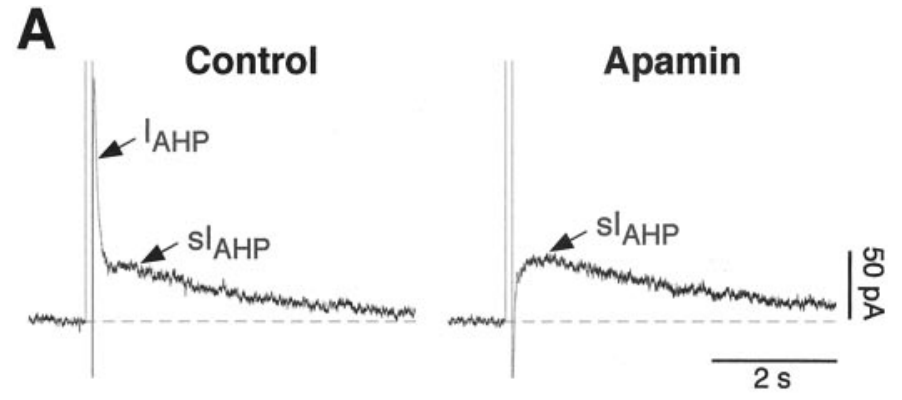

B
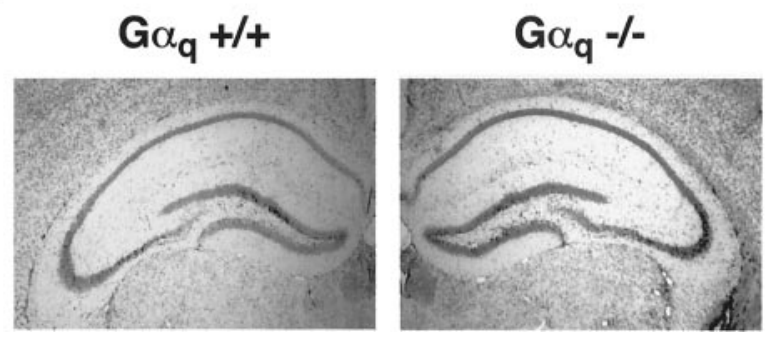

Figure 1. A, Mouse CA1 pyramidal neurons present a $\mathrm{Ca}^{2+}$-activated, apamin-sensitive afterhyperpolarizing current $\left(I_{\mathrm{AHP}}\right)$ that deactivates in the hundreds of milliseconds range, followed by a $\mathrm{Ca}^{2+}$-activated, apamin-insensitive AHP current ( $\left.\mathrm{s}_{\mathrm{AHP}}\right)$, lasting seconds. $I_{\mathrm{AHP}}$ is partially overlapping with the rise time of $\mathrm{s} I_{\mathrm{AHP}}$. These currents were elicited by $\mathrm{Ca}^{2+}$ influx induced by a $100 \mathrm{msec}$ depolarizing pulse to $+10 \mathrm{mV}$. Traces shown were recorded from CA1 neurons of a $\mathrm{G} \alpha_{11}-/-$ mouse. $\mathrm{G} \alpha_{11}+/+$ littermates, as well as $\mathrm{G} \alpha_{\mathrm{q}}+/+$ and $\mathrm{G} \alpha_{\mathrm{q}}-/-$ mice, displayed similar currents (see Results). In the right panel, $I_{\mathrm{AHP}}$ was blocked by 50 $\mathrm{nM}$ apamin, leaving $\mathrm{s} I_{\mathrm{AHP}}$ amplitude and kinetics unaffected. $B$, Nissl stains of the hippocampal formation from $\mathrm{G} \alpha_{\mathrm{q}}+/+$ and $\mathrm{G} \alpha_{\mathrm{q}}-/-$ mice. No changes in the gross morphology of the hippocampus were observed in the knock-out animals when compared with their wild-type littermates.

determined at a point $700-800 \mathrm{msec}$ after the end of the command pulse, in which a possible contamination by the partially overlapping $I_{\mathrm{AHP}}$ was negligible (Stocker et al., 1999). Values are presented as mean \pm SEM. For statistical analysis, the unpaired, two-tailed Student's $t$ test was used, and differences were considered statistically significant if $p \leq 0.05$.

Drugs and solutions. TEA, carbamylcholine (carbachol, $\mathrm{CCh}$ ), $\mathrm{Na}_{2-}$ ATP, and $\mathrm{Na}_{3}$-GTP were obtained from Sigma (St. Louis, MO). TTX was from Alomone Labs (Jerusalem, Israel). Picrotoxin and isoproterenol were from Research Biochemicals (Natick, MA). trans-1-Aminocyclopentyl-1,3-dicarboxylate (trans-ACPD) and (S)-3,5dihydroxyphenyl-glycine (DHPG) were from Tocris Cookson (Bristol, UK). All drugs were dissolved in water, stored at $+4^{\circ} \mathrm{C}$ or $-20^{\circ} \mathrm{C}$, and bath applied in the perfusing ACSF.

\section{RESULTS}

\section{AHP currents in the mouse hippocampus}

Rat CA1 pyramidal neurons have been shown to present two distinct $\mathrm{Ca}^{2+}$-dependent afterhyperpolarizing currents, contributing to the early and late spike frequency adaptation: $I_{\mathrm{AHP}}$, deactivating in hundreds of milliseconds and sensitive to the toxin apamin; and $\mathrm{s} I_{\mathrm{AHP}}$, characterized by a slow deactivation (in the range of seconds), insensitive to apamin and sensitive to the neuromodulatory effects of a number of transmitters (Stocker et al., 1999). In mouse hippocampal pyramidal neurons, the types of AHP currents and their key features are still unexplored. In CA1 pyramidal neurons from mouse slices, short depolarizing pulses inducing $\mathrm{Ca}^{2+}$ influx elicited an apamin-sensitive $I_{\mathrm{AHP}}$ in $94.9 \%$ of the cells, followed by an apamin-insensitive $\mathrm{s} I_{\mathrm{AHP}}$ in $77.8 \%$ (Fig. $1 A$ ). In two different strains of wild-type mice tested, NMRI and $\mathrm{C} 57 \mathrm{BL} / 6, \mathrm{~s} I_{\mathrm{AHP}}$ presented an amplitude of $19.6 \pm 3.5(n=$ 
$11)$ and $25.6 \pm 3.4(n=31) \mathrm{pA}$, respectively, whereas in Wistar rats, the $\mathrm{s} I_{\mathrm{AHP}}$ amplitude was substantially larger $(109.8 \pm 13.5$ $\mathrm{pA} ; n=13$ ) under the same experimental conditions. The time courses of decay of the two AHP currents were clearly different: the apamin-sensitive $I_{\mathrm{AHP}}$ presented an average decay time constant of $88.3 \pm 4.9 \mathrm{msec}$, and the apamin-insensitive $\mathrm{s} I_{\mathrm{AHP}}$ presented an average decay time constant of $3.5 \pm 0.2 \mathrm{sec}$. In most cells measured, $I_{\mathrm{AHP}}$ coexisted and partially overlapped with the rising phase of $\mathrm{s}_{\mathrm{AHP}}$, as shown in Figure $1 A$ (left panel). The pharmacological separation by apamin (Fig. $1 A$ ) suggests that $I_{\mathrm{AHP}}$ and $I_{\mathrm{AHP}}$ are distinct currents, as reported previously in rat CA1 pyramidal neurons (Stocker et al., 1999). In all CA1 pyramidal neurons from mouse, as in rat, the $\mathrm{Ca}^{2+}$ spikes and $\mathrm{s} I_{\mathrm{AHP}}$ remained stable for the duration of the recording (usually $\sim 2-3$ hr). Additionally, $\mathrm{s} I_{\mathrm{AHP}}$ displayed a normal sensitivity to a number of neurotransmitters (see below), as observed previously in rat neurons.

\section{Cholinergic and glutamatergic modulation of $s I_{\mathrm{AHP}}$ is inhibited in $\mathbf{G} \alpha_{\mathbf{q}}$-deficient mice}

Activation of muscarinic ( $\mathrm{M}_{3}$; Rouse et al., 2000; M. Krause and P. Pedarzani, unpublished observation) or metabotropic $\left(\mathrm{mGluR}_{5}\right.$; Gereau and Conn, 1995) glutamate receptors leads to the suppression of the apamin-insensitive $s I_{\mathrm{AHP}}$ in CA1 pyramidal neurons. The actions of both muscarinic and $\mathrm{mGluR}$ agonists on $\mathrm{s} I_{\mathrm{AHP}}$ have been shown to involve activation of G-proteins of the pertussis toxin-insensitive type (Dutar and Nicoll, 1988; Gerber et al., 1992; Abdul-Ghani et al., 1996a; Krause and Pedarzani, 2000). However, pertussis toxin and GDP- $\beta$-S used in those studies blocked a wide subset or all G-proteins, respectively. Therefore, this approach did not allow the identification of specific G-protein subtypes transducing the effects of $\mathrm{M}_{3}$ muscarinic and $\mathrm{mGluR}_{5}$ receptor stimulation on $\mathrm{s}_{\mathrm{AHP}}$. We used mice deficient in the $\mathrm{G} \alpha_{\mathrm{q}}$ gene $\left(\mathrm{G} \alpha_{\mathrm{q}}-/-\right)$ to investigate the specific role of this $\mathrm{G}$-protein in the cholinergic and glutamatergic modulation of $\mathrm{s} I_{\mathrm{AHP}}$. The hippocampus of $\mathrm{G} \alpha_{\mathrm{q}}$-deficient mice presented an overall structure and gross morphology indistinguishable from those of wild-type animals (Fig. $1 B$ ). Additionally, s $I_{\mathrm{AHP}}$ amplitude, time course, and passive membrane properties (resting membrane potential, $V_{\mathrm{m}}$; input resistance, $R_{\mathrm{i}}$ ) were not significantly different in $\mathrm{G} \alpha_{\mathrm{q}}-/-\left(V_{\mathrm{m}}\right.$ of $-71.0 \pm 1.4 \mathrm{mV} ; R_{\mathrm{i}}$ of $186 \pm$ $9 \mathrm{M} \Omega$ ) when compared with $\mathrm{G} \alpha_{\mathrm{q}}+/+$ mice $\left(V_{\mathrm{m}}\right.$ of $-72.4 \pm 1.2$ $\mathrm{mV} ; R_{\mathrm{i}}$ of $190 \pm 11 \mathrm{M} \Omega$ ) or mice of a different strain (NMRI; $V_{\mathrm{m}}$ of $-68.3 \pm 1.8 \mathrm{mV} ; R_{\mathrm{i}}$ of $173 \pm 13 \mathrm{M} \Omega$ ). The only observed difference was an intrinsically smaller amplitude of the apaminsensitive $I_{\text {AHP }}$ in the absence of neuromodulatory agents in $\mathrm{G} \alpha_{\mathrm{q}}$ $-/-$ mice $\left(87.6 \pm 15.9 \mathrm{pA}\right.$ in $\mathrm{G} \alpha_{\mathrm{q}}+/+, n=25 ; 44.1 \pm 5.0 \mathrm{pA}$ in $\left.\mathrm{G} \alpha_{\mathrm{q}}-/-, n=19 ; p=0.01\right)$.

In wild-type mice, the cholinergic agonist carbachol $(5 \mu \mathrm{M})$ (Fig. 2A,E) and the mGluR agonists DHPG (2-3 $\mu \mathrm{M}$ ) (Fig. $3 A, E)$ and trans-ACPD (10-20 $\mu \mathrm{M}$; data not shown) all produced a robust inhibition of $\mathrm{s} I_{\mathrm{AHP}}$ but did not significantly affect the apamin-sensitive $I_{\mathrm{AHP}}$. In mice lacking $\mathrm{G} \alpha_{\mathrm{q}}$, the effects of carbachol and DHPG on $\mathrm{s} I_{\mathrm{AHP}}$ were strongly reduced (Fig. $2 C, E$ for CCh; Fig. $3 C, E$ for DHPG), arguing in favor of a substantial contribution of $\mathrm{G} \alpha_{\mathrm{q}}$ in mediating the suppression of $\mathrm{s} I_{\mathrm{AHP}}$. The apparent small decrease in $I_{\mathrm{AHP}}$ amplitude, observed in wild-type as in knock-out $\mathrm{G} \alpha_{\mathrm{q}}$ mice during application of these neuromodulatory agents, was most likely attributable to the partial overlap between $I_{\mathrm{AHP}}$ and $\mathrm{s} I_{\mathrm{AHP}}$ and the concomitant suppression of $\mathrm{s} I_{\text {AHP }}$ (Stocker et al., 1999).

Beside downregulating $\mathrm{s}_{\mathrm{AHP}}$, activation of $\mathrm{M}_{3}$ receptors and
A

$$
\mathrm{G} \alpha_{\mathrm{q}}+/+
$$

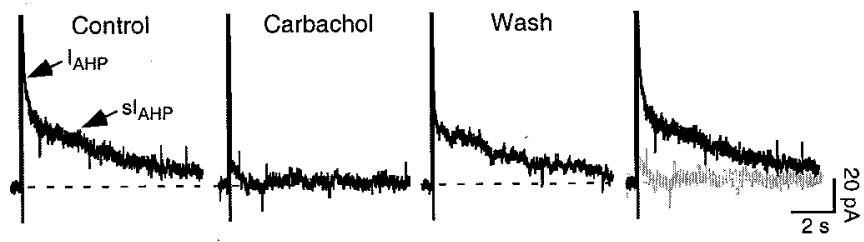

$\mathbf{B}$

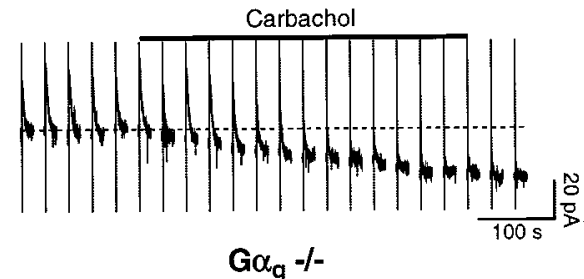

C $\mathrm{G} \alpha_{q}-/$

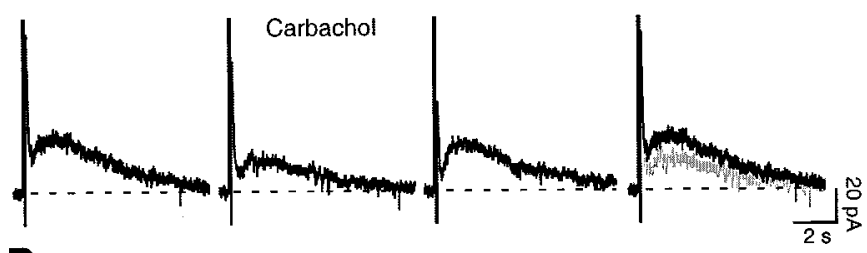

D

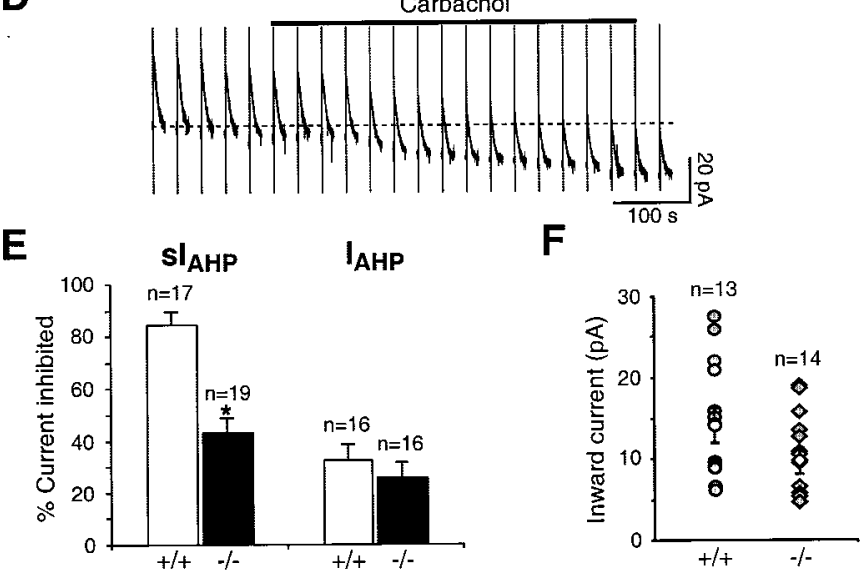

Figure 2. A, In $\mathrm{G} \alpha_{\mathrm{q}}+/+$ mice, the cholinergic agonist carbachol $(5 \mu \mathrm{M})$ strongly and reversibly suppressed $\mathrm{s}_{\mathrm{AHP}} . B$, Voltage-clamp recording of the inward current underlying the depolarizing response to carbachol (5 $\mu \mathrm{M})$ in CA1 neurons from $\mathrm{G} \alpha_{\mathrm{q}}+/+$ mice. The vertical lines correspond to depolarizing pulses used to elicit the AHP currents once every $30 \mathrm{sec}$. The dotted line represents the baseline holding current before the application of carbachol. The carbachol application lasted $7 \mathrm{~min}$ (solid bar). $C$, In $\mathrm{G} \alpha_{\mathrm{q}}-/-$ mice, $5 \mu \mathrm{M}$ carbachol induced a significantly smaller inhibition of $\mathrm{s} I_{\mathrm{AHP}}$ than in $A$. In $A$ and $C$, the rightmost panels show superimpositions of the traces before and during carbachol application. $D$, Inward current underlying the depolarizing response to carbachol $(5 \mu \mathrm{M})$ in CA1 neurons from $\mathrm{G} \alpha_{\mathrm{q}}-/-$ mice. The carbachol application lasted $7.5 \mathrm{~min}$ (solid bar). All of the rest are as in B.E, Summary of the results obtained with carbachol in CA1 pyramidal neurons from $\mathrm{G} \alpha_{\mathrm{q}}+/+$ and $\mathrm{G} \alpha_{\mathrm{q}}-/-$ mice. In $\mathrm{G} \alpha_{\mathrm{q}}+/+$, carbachol suppressed $\mathrm{s} I_{\mathrm{AHP}}$ by $84.0 \pm 4.2 \%(n=17)$, whereas in $\mathrm{G} \alpha_{\mathrm{q}}-/-, 42.6 \pm 5.6 \%$ of $\mathrm{s} I_{\mathrm{AHP}}$ was inhibited during carbachol application $(n=19)$. *represents a statistically significant difference $(p<$ $0.001)$. In the same pools of CA1 neurons, carbachol did not significantly downregulate $I_{\mathrm{AHP}}$ in $\mathrm{G} \alpha_{\mathrm{q}}+/+$ mice $(31.8 \pm 5.9 \%$ inhibition) compared with $\mathrm{G} \alpha_{\mathrm{q}}-/-$ mice $(25.5 \pm 5.5 \%$ inhibition; $n=16 ; p=0.44) . F$, Scatter plot summarizing the effect of $5 \mu \mathrm{M}$ carbachol on the membrane potential of CA1 pyramidal neurons from $\mathrm{G} \alpha_{\mathrm{q}}+/+$ (filled circles) and $\mathrm{G} \alpha_{\mathrm{q}}-/-$ ( filled diamonds) animals. Carbachol elicited a mean inward shift in the holding current of $14.6 \pm 2.0 \mathrm{pA}$ in $\mathrm{G} \alpha_{\mathrm{q}}+/+$ (open circle; $n=13$ ) and $10.3 \pm 1.4 \mathrm{pA}$ in $\mathrm{G} \alpha_{\mathrm{q}}-/-$ mice (open diamond; $n=14 ; p=0.10$ ). 

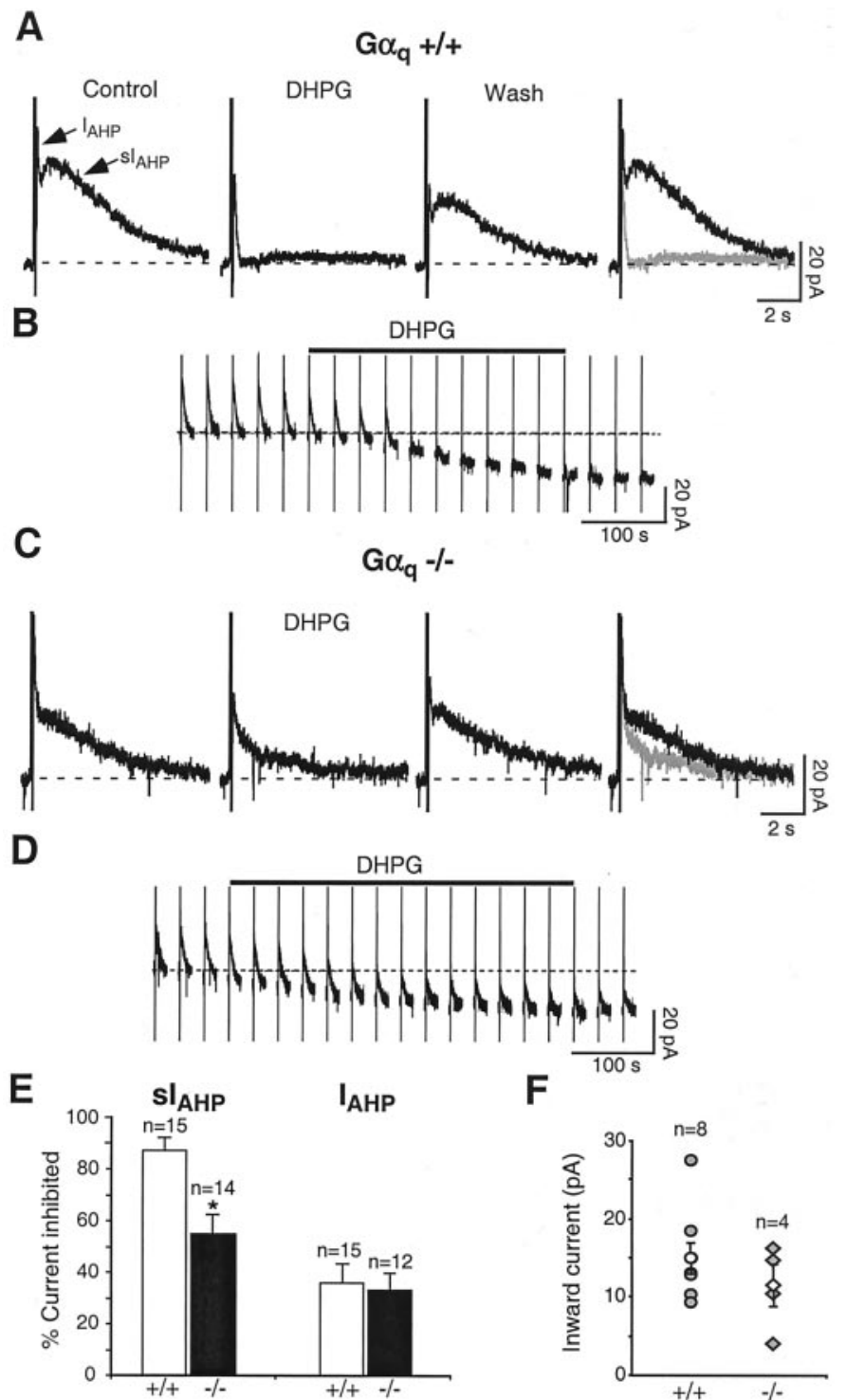

Figure 3. A, The group I mGluR receptor agonist DHPG $(3 \mu \mathrm{M})$ suppressed $\mathrm{s} I_{\mathrm{AHP}}$ in a reversible manner in $\mathrm{G} \alpha_{\mathrm{q}}+/+$ mice. $B$, Inward shift in the holding current underlying the depolarizing response to DHPG (3 $\mu \mathrm{M})$ in CA1 neurons from $\mathrm{G} \alpha_{\mathrm{q}}+/+$ mice. The vertical lines correspond to depolarizing pulses used to elicit the AHP currents once every $30 \mathrm{sec}$. The dotted line represents the baseline holding current before the application of DHPG. The DHPG application lasted 5 min (solid bar). $C$, In $\mathrm{G} \alpha_{\mathrm{q}}-/-$ mice, $3 \mu \mathrm{M}$ DHPG produced a significantly smaller inhibition of $s I_{\mathrm{AHP}}$. In $A$ and $C$, the rightmost panels show superimpositions of the traces before and during DHPG application. $D$, Depolarizing current elicited in response to DHPG $(3 \mu \mathrm{M})$ in CA1 neurons from $\mathrm{G} \alpha_{\mathrm{q}}-/-$ mice. The DHPG application lasted $7 \mathrm{~min}$ (solid bar). All of the rest are as in B. E, Bar diagram summarizing the results obtained with DHPG in CA1 pyramidal neurons from $\mathrm{G} \alpha_{\mathrm{q}}+/+$ and $\mathrm{G} \alpha_{\mathrm{q}}-/-$. In $\mathrm{G} \alpha_{\mathrm{q}}+/+, 86.9 \pm$ $4.4 \%$ of $\mathrm{s} I_{\mathrm{AHP}}$ was inhibited after DHPG application $(n=15)$, whereas in $\mathrm{G} \alpha_{\mathrm{q}}-/-$, DHPG suppressed $\mathrm{s} I_{\mathrm{AHP}}$ by $54.7 \pm 7.3 \%(n=14)$. *represents a statistically significant difference $(p=0.001)$. In the same pools of CA1 neurons, the small inhibitory effect of DHPG on $I_{\mathrm{AHP}}$ was similar in $\mathrm{G} \alpha_{\mathrm{q}}+/+(35.9 \pm 7.4 \%$ inhibition; $n=15)$ and $\mathrm{G} \alpha_{\mathrm{q}}-/-(32.5 \pm 6.2 \%$ inhibition; $n=12 ; p=0.73$ ) mice. $F$, Summary of the effect of DHPG (2-3 $\mu \mathrm{M})$ on the holding current in $\mathrm{G} \alpha_{\mathrm{q}}+/+$ ( filled circles) and $\mathrm{G} \alpha_{\mathrm{q}}-/-$ ( filled diamonds) neurons. DHPG elicited a mean inward depolarizing current of $15.2 \pm 2.0 \mathrm{pA}$ in $\mathrm{G} \alpha_{\mathrm{q}}+/+$ (open circle; $\left.n=8\right)$ and $11.8 \pm 2.7$ $\mathrm{pA}$ in $\mathrm{G} \alpha_{\mathrm{q}}-/-$ (open diamond; $n=4 ; p=0.33$ ).
$\mathrm{mGluR}_{5}$ leads to the generation of a depolarizing inward current in CA1 pyramidal neurons (Figs. 2B, 3B) (Pitler and Alger, 1990; Gereau and Conn, 1995). The signal transduction pathway leading to this depolarizing effect is only partly known. We tested whether $\mathrm{G} \alpha_{\mathrm{q}}$ was mediating the generation of the depolarizing current during application of muscarinic and mGluR agonists. The inward current elicited by carbachol and DHPG was not significantly different in $\mathrm{G} \alpha_{\mathrm{q}}$ knock-out mice (Fig. 2D, $F$ for CCh; Fig. $3 D, F$ for DHPG) when compared with their wild-type littermates (Fig. $2 B, F$ for CCh; Fig. $3 B, F$ for DHPG). These results suggest that $\mathrm{G} \alpha_{\mathrm{q}}$ is not required for the muscarinic- or mGluRinduced depolarizing inward current in CA1 neurons.

\section{$\mathrm{G} \alpha_{11}$ is not required for the modulation of $s l_{A H P}$ by muscarinic and mGluR agonists}

The remaining effect of muscarinic and $\mathrm{mGluR}$ agonists on $\mathrm{s} I_{\mathrm{AHP}}$ in $\mathrm{G} \alpha_{\mathrm{q}}$-deficient mice might be attributable to activation of $\mathrm{G} \alpha_{11}$, because this $\mathrm{G} \alpha$ subunit is also expressed, although to a lower level, in CA1 pyramidal neurons (Mailleux et al., 1992; Milligan, 1993; Tanaka et al., 2000) and displays a similar functional role as $\mathrm{G} \alpha_{\mathrm{q}}$ in other systems (Wu et al., 1992; Offermanns et al., 1994; Exton, 1996; Offermanns, 1999). To investigate the role of $\mathrm{G} \alpha_{11}$ in the cholinergic and metabotropic signal transduction cascades suppressing $\mathrm{s} I_{\mathrm{AHP}}$, we recorded from CA1 neurons of mice lacking $\mathrm{G} \alpha_{11}\left(\mathrm{G} \alpha_{11}-/-\right)$. As in the case of the $\mathrm{G} \alpha_{\mathrm{q}}$ knock-outs, mice lacking $\mathrm{G} \alpha_{11}$ presented a normal hippocampal gross morphology and intrinsic neuronal properties indistinguishable from those of control mice (data not shown). In $\mathrm{G} \alpha_{11}-/-$ mice and in their wild-type littermates $\left(\mathrm{G} \alpha_{11}+/+\right)$, carbachol (Fig. 4A,C) and DHPG (Fig. $4 B, D$ ) suppressed $\mathrm{s} I_{\mathrm{AHP}}$ to the same extent. In the same neurons, the apamin-sensitive $I_{\mathrm{AHP}}$ was only marginally affected by application of muscarinic (Fig. 4C) and mGluR (Fig. $4 D$ ) agonists. These results demonstrate that $\mathrm{G} \alpha_{11}$ is not required to transduce the cholinergic and glutamatergic signals that result in the downregulation of $\mathrm{s} I_{\mathrm{AHP}}$. Therefore, it is unlikely that $\mathrm{G} \alpha_{11}$ is part of the signal cascade regulating the residual $\mathrm{s} I_{\mathrm{AHP}}$ present in $\mathrm{G} \alpha_{\mathrm{q}}-/-$ after cholinergic and glutamatergic receptor activation. In mice lacking $\mathrm{G} \alpha_{11}$, the depolarizing effects of carbachol and DHPG were indistinguishable from those observed in their wild-type littermates (data not shown), suggesting that $\mathrm{G} \alpha_{11}$ is not mediating the muscarinic- or mGluR-induced depolarizing inward current in CA1 neurons.

\section{The $\beta$-adrenergic modulation of $s I_{A H P}$ is intact in $\mathbf{G} \alpha_{q^{-}}$ deficient mice}

Next, we wanted to test whether the reduction of the effects of cholinergic and glutamatergic agonists on $\mathrm{s} I_{\mathrm{AHP}}$ observed in $\mathrm{G} \alpha_{\mathrm{q}}$-deficient mice is specific or whether supposedly unrelated modulatory pathways converging on $\mathrm{s} I_{\mathrm{AHP}}$ might be unspecifically affected in these genetically modified animals. To this purpose, we took advantage of the fact that $\mathrm{s} \mathrm{AHP}_{\mathrm{AH}}$ is strongly suppressed by monoamine transmitters (noradrenaline, serotonin, histamine, and dopamine) in rat CA1 pyramidal neurons (Nicoll, 1988; Pedarzani and Storm, 1993; Pedarzani and Storm, 1995). Among these transmitters, noradrenaline activates $\beta$-adrenergic receptors, which are coupled to $\mathrm{G} \alpha_{\mathrm{s}}$-subunits and lead to the stimulation of adenylyl cyclase, increase of cAMP level, and activation of PKA, finally resulting in a complete suppression of $I_{\mathrm{AHP}}$. We used the $\beta$-adrenergic agonist isoproterenol, which suppressed $\mathrm{s} I_{\mathrm{AHP}}$ both in wild-type (Fig. $5 A, C$ ) and $\mathrm{G} \alpha$-deficient (Fig. $5 B, C)$ mice in an indistinguishable manner but had no significant effect on the apamin-sensitive $I_{\mathrm{AHP}}$ (Fig. 5C). We can therefore 
A

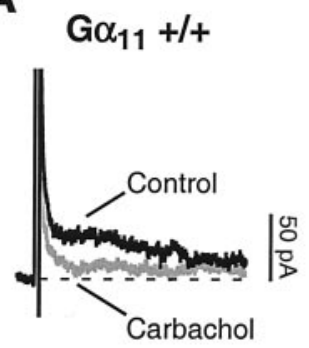

B

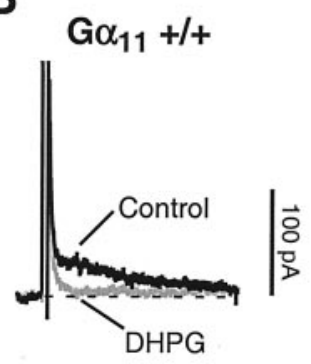

C

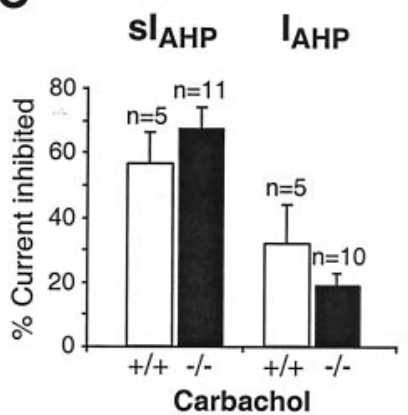

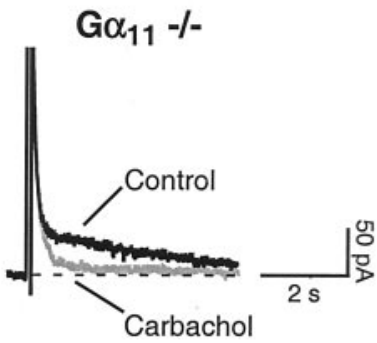
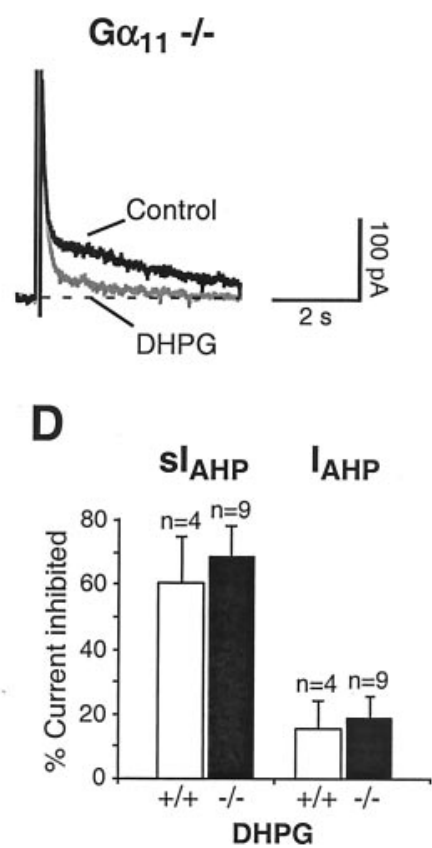

Figure 4. A, Left , In $\mathrm{G} \alpha_{11}+/+$ mice, $5 \mu \mathrm{M}$ carbachol strongly suppressed $\mathrm{s} I_{\mathrm{AHP}}$. Right, In $\mathrm{G} \alpha_{11}-/-, 5 \mu \mathrm{M}$ carbachol inhibited $\mathrm{s} I_{\mathrm{AHP}}$ to the same extent as observed in $\mathrm{G} \alpha_{11}+/+$ mice. $B$, Left, DHPG $(3 \mu \mathrm{M})$ induced a robust suppression of $\mathrm{s} I_{\mathrm{AHP}}$ in $\mathrm{G} \alpha_{11}+/+$ mice. Right, Similarly, in $\mathrm{G} \alpha_{11}$ $-/-, 3 \mu \mathrm{M}$ DHPG produced a strong inhibition of $I_{\mathrm{AHP}}$. In $A$ and $B$, traces before and during carbachol and DHPG applications are shown superimposed. $C$, Bar diagram summarizing the results obtained with carbachol in CA1 pyramidal neurons from $\mathrm{G} \alpha_{11}+/+$ and $\mathrm{G} \alpha_{11}-/-$ mice. In $\mathrm{G} \alpha_{11}+/+$, carbachol suppressed $\mathrm{s} I_{\mathrm{AHP}}$ by $56.2 \pm 9.8 \%(n=5)$, and in $\mathrm{G} \alpha_{11},-/-, 67.3 \pm 7.2 \%$ of $\mathrm{s} I_{\mathrm{AHP}}$ was inhibited during carbachol application $(n=11)$. The difference observed between $\mathrm{G} \alpha_{11}+/+$ and $\mathrm{G} \alpha_{11}$ $-/-$ mice was not statistically significant $(p=0.39)$. In the same pools of CA1 neurons, carbachol did not significantly affect $I_{\mathrm{AHP}}$ in $\mathrm{G} \alpha_{11}+/+$ compared with $\mathrm{G} \alpha_{11}-/-$ mice ( $n=5$ and $n=10$, respectively). $D$, Bar diagram summarizing the results obtained with DHPG in CA1 pyramidal neurons from $\mathrm{G} \alpha_{11}+/+$ and $\mathrm{G} \alpha_{11}-/-$ mice. In $\mathrm{G} \alpha_{11}+/+, 60.5 \pm 14.2 \%$ of $\mathrm{s} I_{\mathrm{AHP}}$ was inhibited during DHPG application $(n=4)$, and in $\mathrm{G} \alpha_{11}$ $-/-$, DHPG suppressed $\mathrm{s} I_{\mathrm{AHP}}$ by $68.0 \pm 9.6 \%(n=9)$. The difference observed between $\mathrm{G} \alpha_{11}+/+$ and $\mathrm{G} \alpha_{11}-/-$ mice was not statistically significant $(p=0.68)$. In the same pools of CA1 neurons, DHPG did not significantly affect $I_{\mathrm{AHP}}$ in $\mathrm{G} \alpha_{11}+/+$ compared with $\mathrm{G} \alpha_{11}-/-$ mice $(n=$ 4 and $n=9$, respectively).

conclude that the absence of $\mathrm{G} \alpha_{\mathrm{q}}$ impairs specifically cholinergic and glutamatergic signal cascades suppressing $\mathrm{s}_{\mathrm{AHP}}$, but it does not affect the modulation of this current by other neurotransmitters coupled to different second-messenger pathways.

\section{DISCUSSION}

This study presents the first demonstration and characterization of apamin-sensitive and -insensitive AHP currents in the mouse

A
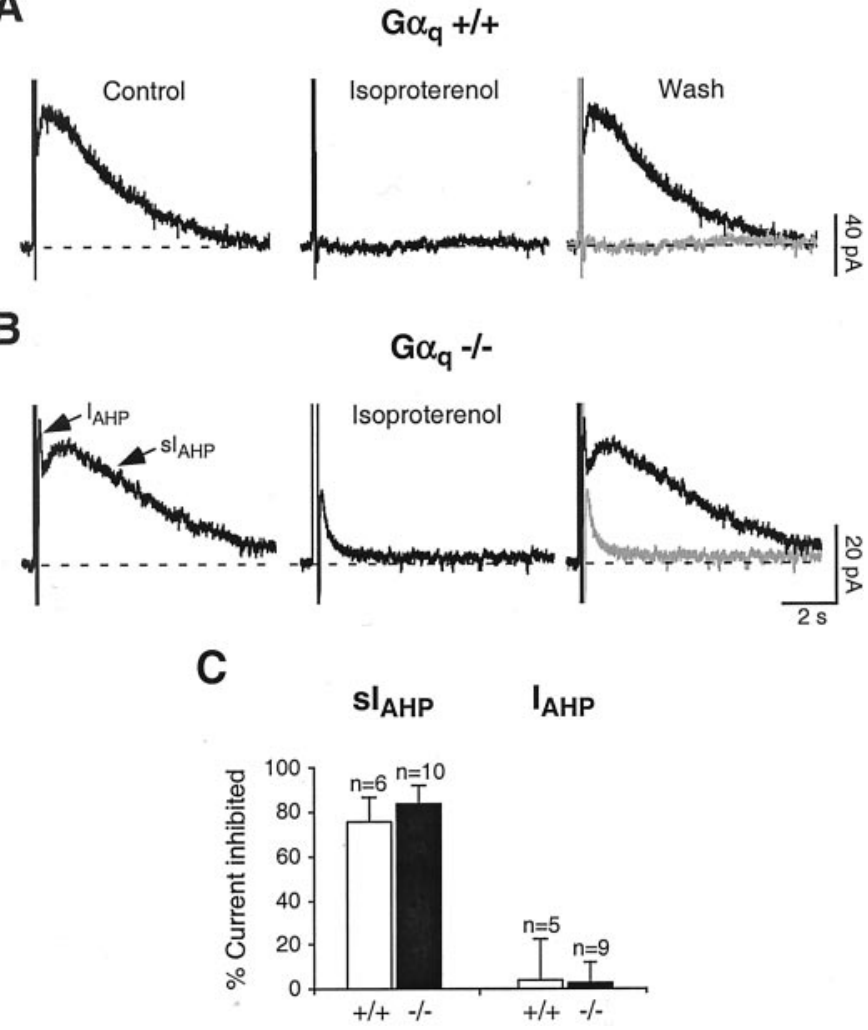

Figure 5. $A$, In $\mathrm{G} \alpha_{\mathrm{q}}+/+$, the $\beta$-adrenergic agonist isoproterenol $(1 \mu \mathrm{M})$ strongly suppressed $\mathrm{s} I_{\mathrm{AHP}} . B$, In $\mathrm{G} \alpha_{\mathrm{q}}-/-, 1 \mu \mathrm{M}$ isoproterenol suppressed $\mathrm{s} I_{\mathrm{AHP}}$ to a similar extent as in $A$. In $A$ and $B$, the rightmost panels show superimpositions of the traces before and during isoproterenol application. $C$, Summary of the results obtained with isoproterenol in CA1 pyramidal neurons from $\mathrm{G} \alpha_{\mathrm{q}}+/+$ and $\mathrm{G} \alpha_{\mathrm{q}}-/-$ mice. In $\mathrm{G} \alpha_{\mathrm{q}}+/+$, isoproterenol suppressed $\mathrm{SI}_{\mathrm{AHP}}$ by $75.0 \pm 11.4 \%(n=6)$, and in $\mathrm{G} \alpha_{\mathrm{q}}-/-$, $83.6 \pm 7.8 \%$ of $\mathrm{s} I_{\mathrm{AHP}}$ was inhibited during isoproterenol application $(n=$ 10). The difference observed between $\mathrm{G} \alpha_{\mathrm{q}}+/+$ and $\mathrm{G} \alpha_{\mathrm{q}}-/-$ mice was not statistically significant $(p=0.54)$. In the same pools of CA1 neurons, isoproterenol did not affect $I_{\mathrm{AHP}}$ in $\mathrm{G} \alpha_{\mathrm{q}}+/+$ differently from $\mathrm{G} \alpha_{\mathrm{q}}-/-$ mice ( $n=5$ and $n=9$, respectively).

hippocampus. Based on this, knock-out animals could be used to analyze specific transducing elements of signal cascades regulating $\mathrm{s} I_{\mathrm{AHP}}$. The primary purpose of the present experiments was to elucidate which heterotrimeric G-proteins transduce muscarinic- and mGluR-mediated signals leading to a downregulation of $\mathrm{s} I_{\mathrm{AHP}}$ and to an enhanced excitability of hippocampal pyramidal neurons. To this purpose, we used mice lacking the $\mathrm{G} \alpha_{\mathrm{q}}$ or $\mathrm{G} \alpha_{11}$ gene. These mice did not present gross morphological abnormalities of the CNS and displayed an overall normal hippocampal morphology. In addition, intrinsic membrane properties (this study) and basic parameters of synaptic function (input-output curves and paired-pulse facilitation; Kleppisch et al., 2001) were not altered in the CA1 region. Our results demonstrate that $\mathrm{G} \alpha_{\mathrm{q}}$ is the main transducing element in these signal cascades leading to $\mathrm{s} I_{\mathrm{AHP}}$ suppression, whereas $\mathrm{G} \alpha_{11}$ does not seem to be required. Neither $\mathrm{G} \alpha_{\mathrm{q}}$ nor $\mathrm{G} \alpha_{11}$ seem to be involved in mediating the membrane potential depolarization caused by muscarinic and mGluR agonists in CA1 pyramidal neurons.

Muscarinic and mGluR downregulation of $\mathrm{s} I_{\mathrm{AHP}}$ requires $\mathrm{G} \alpha_{\mathrm{q}}$, because the effects of muscarinic and mGluR agonists were strongly reduced in neurons from $\mathrm{G} \alpha_{\mathrm{q}}$ knock-out mice. It is unlikely that this was a result of generalized secondary effects on 
transduction mechanisms arising from the absence of $\mathrm{G} \alpha_{\mathrm{q}}$ during development, because muscarinic and mGluR agonists were still able to elicit the inward, depolarizing current. Furthermore, transmitters acting via other G-proteins, such as the $\beta$-adrenergic agonist isoproterenol acting via $\mathrm{G} \alpha_{\mathrm{s}}$, fully suppressed $\mathrm{s} I_{\mathrm{AHP}}$ in $\mathrm{G} \alpha_{\mathrm{q}}$-deficient neurons, indicating a preserved function of other signaling pathways targeting the same current.

In the absence of $\mathrm{G} \alpha_{\mathrm{q}}$, muscarinic and $\mathrm{mGluR}$ agonists partially suppressed $\mathrm{s} I_{\mathrm{AHP}}$ (Figs. 2, 3). Our first assumption was that this could be attributable to the presence of $\mathrm{G} \alpha_{11}$, which is expressed at lower levels in hippocampal neurons (Mailleux et al., 1992; Milligan, 1993; Tanaka et al., 2000) and presents receptorand effector-coupling properties very similar to $\mathrm{G} \alpha_{\mathrm{q}}$ (Wu et al., 1992; Offermanns et al., 1994; Exton, 1996; Offermanns, 1999). However, the results we obtained in $\mathrm{G} \alpha_{11}$ knock-out mice revealed that $\mathrm{G} \alpha_{11}$ is not required for $\mathrm{s} I_{\mathrm{AHP}}$ modulation and is therefore unlikely to substitute for $\mathrm{G} \alpha_{\mathrm{q}}$ in $\mathrm{G} \alpha_{\mathrm{q}}$ knock-out mice. This observation is further supported by the lack of compensatory overexpression of $\mathrm{G} \alpha_{11}$ in the hippocampus of $\mathrm{G} \alpha_{\mathrm{q}}$ knockout mice, as shown recently by immunoblot experiments (Kleppisch et al., 2001). Despite this evidence, in principle the possibility remains that $\mathrm{G} \alpha{ }_{11}$ mediates the residual effect of muscarinic and glutamatergic agonists observed in $\mathrm{G} \alpha$, knockout mice. This could happen, for example, if $\mathrm{G} \alpha_{11}$ contributed in a small but significant way to the muscarinic or glutamatergic action, resulting in an invisible phenotype in the $\mathrm{G} \alpha_{11}$ knock-out mice but emerging as a sufficient contribution in the $\mathrm{G} \alpha_{\mathrm{q}}$ knockouts. A subtle, partial effect linked to $\mathrm{G} \alpha_{11}$, unmasked in $\mathrm{G} \alpha_{\mathrm{q}}$ knock-out mice, would be expected to be slower when compared with the $\mathrm{G} \alpha_{\mathrm{q}}$-mediated effect observed in their wild-type littermates, given the lower density of the $\mathrm{G} \alpha_{11}$ subtype in CA1 pyramidal neurons (Mailleux et al., 1992; Milligan, 1993; Tanaka et al., 2000). Indeed, a compensatory phenomenon with altered (slower) kinetics has been reported recently for the modulation of potassium and calcium channels by $\mathrm{GABA}_{\mathrm{B}}$ and adenosine receptors in hippocampal neurons from mice lacking $\mathrm{G} \alpha_{\mathrm{o}}$ (Greif et al., 2000). This seems unlikely to occur in our case, because the time course of the residual muscarinic and glutamatergic effects on $\mathrm{s} I_{\mathrm{AHP}}$ was not different in $\mathrm{G} \alpha_{\mathrm{q}}$ knock-out mice when compared with their wild-type littermates [compare Figs. $2 B, D$ (for carbachol, $3 B, D$ (for DHPG)]. However, the possibility of a marginal $\mathrm{G} \alpha_{11}$ involvement could be conclusively ruled out only by using animal models lacking both $\mathrm{G} \alpha_{\mathrm{q}}$ and $\mathrm{G} \alpha_{11}$ subunits, but unfortunately a double mutant generated by conventional gene targeting is not viable (Offermanns et al., 1998). If conditional double mutants prove to be viable, they could provide a potential future approach to unequivocally answer this question.

In several mammalian cells, receptors activating $G_{q}$ family members do not seem to discriminate between $\mathrm{G} \alpha_{\mathrm{q}}$ and $\mathrm{G} \alpha_{11}$ (Wange et al., 1991; Wu et al., 1992; Offermanns et al., 1994), and, in reconstituted systems, both G-proteins are indistinguishable in their ability to regulate different phospholipase C (PLC) isoforms (Exton, 1996) and inward rectifier potassium channels (Lei et al., 2001). In the light of such apparent functional redundancy, the prominent involvement of $\mathrm{G} \alpha_{\mathrm{q}}$ and the lack of effect of $\mathrm{G} \alpha_{11}$ in mediating the cholinergic and glutamatergic suppression of $\mathrm{s}_{\mathrm{AHP}}$ provide therefore a remarkable indication of functional specificity for members of the $\mathrm{G}_{\mathrm{q}}$ family in the CNS. In line with this view, $\mathrm{G} \alpha_{\mathrm{q}}$, but not $\mathrm{G} \alpha_{11}$, has been shown recently to be critically involved in the induction of mGluR-dependent long-term depression in CA1 pyramidal neurons (Kleppisch et al., 2001).

The picture emerging from the results presented here is differ- ent from that which has been observed for another potassium current, the voltage-dependent $I_{\mathrm{M}}$, in the peripheral nervous system. In rat superior cervical ganglion neurons, $\mathbf{M}_{1}$ muscarinic receptors inhibit $I_{\mathrm{M}}$ primarily via $\mathrm{G} \alpha_{\mathrm{q}}$ (Haley et al., 1998). In mouse, inhibition is also mediated by $\mathrm{M}_{1}$ receptors (Hamilton et al., 1997) but appears to involve both $\mathrm{G} \alpha_{\mathrm{q}}$ and $\mathrm{G} \alpha_{11}$ and also a pertussis toxin-sensitive G-protein (Haley et al., 2000). The suppression of $\mathrm{s} I_{\mathrm{AHP}}$ by muscarinic agonists in CA1 neurons is instead linked to $M_{3}$ receptor activation (Rouse et al., 2000) and is mediated principally by $\mathrm{G} \alpha_{\mathrm{q}}$, in a similar way to that observed for the $\mathrm{M}_{1}$-mediated inhibition of the $\mathrm{N}$-type calcium current in sympathetic neurons (Haley et al., 2000). The preponderant involvement of $\mathrm{G} \alpha_{\mathrm{q}}$ in the $\mathrm{M}_{3}$ - and $\mathrm{mGluR}_{5}$-mediated suppression of $\mathrm{s} I_{\mathrm{AHP}}$ presented in this study is in agreement with previous works using pharmacological approaches to show that G-proteins, and in particular pertussis toxin-insensitive ones, were essential components of the muscarinic and mGluR signal cascades converging on $I_{\mathrm{AHP}}$ (Dutar and Nicoll, 1988; Gerber et al., 1992; Abdul-Ghani et al., 1996a; Krause and Pedarzani, 2000).

Beside modulating $\mathrm{s}_{\mathrm{AHP}}$, muscarinic and mGluR agonists induce a depolarization of the membrane potential in CA1 neurons. The underlying current has been ascribed to the inhibition of at least two types of $\mathrm{K}^{+}$currents: the voltage-dependent $\mathrm{M}$ current (Brown and Adams, 1980; Halliwell and Adams, 1982; McCormick and Williamson, 1989) and a voltage-independent leak current (Madison et al., 1987; Guerineau et al., 1994). More recently, a cation nonselective current has been proposed to be mainly responsible for the depolarization generated by muscarinic and mGluR agonists in cortical and hippocampal neurons (Crepel et al., 1994; Greene et al., 1994; Guerineau et al., 1995; HajDahmane and Andrade, 1997, 1999). Interestingly, mGluR ${ }_{1}$ receptors have been shown recently to elicit an inward, depolarizing current associated with a slow excitatory postsynaptic response in a G-protein-independent manner in CA3 pyramidal neurons (Heuss et al., 1999). Our experiments show that neither the lack of $\mathrm{G} \alpha_{\mathrm{q}}$ nor $\mathrm{G} \alpha_{11}$ affect the depolarizing action of $\mathrm{M}_{3}$ muscarinic and $\mathrm{mGluR}_{5}$ receptors in CA1 pyramidal neurons. Our results are compatible with the possibility that muscarinic and mGluR agonists induce a depolarization of the membrane potential in a G-protein-independent manner in CA1 neurons, as proposed recently for CA3 neurons (Heuss et al., 1999).

The signal transduction events downstream from $\mathrm{M}_{3}$ or $\mathrm{mGluR}_{5}$ and G-protein activation, leading to $\mathrm{s} I_{\mathrm{AHP}}$ suppression, $I_{\mathrm{K}(\text { leak })}$ inhibition, and activation of a depolarizing cationic conductance, are still rather unclear. Calcium/calmodulin-dependent kinase II has been shown to be involved in the muscarinic, but not in the mGluR, modulation of $\mathrm{s}_{\mathrm{AHP}}$ (Müller et al., 1992; Pedarzani and Storm, 1996), suggesting that the two receptors might be coupled to distinct pathways. In dentate gyrus granule cells, PLC, $\mathrm{IP}_{3}$, and a tyrosine kinase have been reported to mediate the glutamatergic suppression of $\mathrm{s}_{\mathrm{AHP}}$ (Abdul-Ghani et al., 1996a,b), whereas in CA1 pyramidal neurons neither PLC nor $\mathrm{IP}_{3}$ seem to be involved in the inhibition of this current by muscarinic or mGluR agonists (Krause and Pedarzani, 1999, 2000). Instead, we obtained evidence for the involvement of a protein phosphatase (Krause and Pedarzani, 1999, 2000), but the mechanism of coupling to G-proteins needs to be elucidated. The present study provides evidence that signaling of both $\mathrm{M}_{3}$ muscarinic and $\mathrm{mGluR}_{5}$ receptors converge onto the same G-protein, $\mathrm{G} \alpha$, to modulate $\mathrm{s} I_{\mathrm{AHP}}$. Future experiments will show whether the residual effect on $\mathrm{s} I_{\mathrm{AHP}}$ observed in $\mathrm{G} \alpha_{\mathrm{q}}$-deficient mice is attributable to the coupling of $\mathrm{M}_{3}$ and $\mathrm{mGluR}_{5}$ to a parallel, second 
pathway, activated by $\beta \gamma$ subunits, by G-proteins not belonging to the $\mathrm{G}_{\mathrm{q}}$ family, or by a $\mathrm{G}$-protein-independent mechanism.

\section{REFERENCES}

Abdul-Ghani MA, Valiante TA, Carlen PL, Pennefather PS (1996a) Metabotropic glutamate receptors coupled to $\mathrm{IP}_{3}$ production mediate inhibition of $\mathrm{I}_{\mathrm{AHP}}$ in rat dentate granule neurons. J Neurophysiol 76:2691-2700.

Abdul-Ghani MA, Valiante TA, Carlen PL, Pennefather PS (1996b) Tyrosine kinase inhibitors enhance a $\mathrm{Ca}^{2+}$-activated $\mathrm{K}^{+}$current $\left(\mathrm{I}_{\mathrm{AHP}}\right)$ and reduce $\mathrm{I}_{\mathrm{AHP}}$ suppression by a metabotropic glutamate receptor agonist in rat dentate granule neurones. J Physiol (Lond) 496:139-144.

Benardo LS, Prince DA (1982) Cholinergic excitation of mammalian hippocampal pyramidal cells. Brain Res 249:315-331.

Blanton MG, Lo Turco JJ, Kriegstein AR (1989) Whole cell recording from neurons in slices of reptilian and mammalian cerebral cortex. J Neurosci Methods 30:203-210.

Brown DA, Adams PR (1980) Muscarinic suppression of a novel voltage-sensitive $\mathrm{K}^{+}$current in a vertebrate neurone. Nature 283:673-676.

Brown DA, Abogadie FC, Allen TG, Buckley NJ, Caulfield MP, Delmas, P, Haley JE, Lamas JA, Selyanko AA (1997) Muscarinic mechanisms in nerve cells. Life Sci 60:1137-1144.

Buckley NJ, Abogadie FC, Brown DA, Dayrell, M, Caulfield MP, Delmas, P, Haley JE (2000) Use of antisense expression plasmids to attenuate G-protein expression in primary neurons. Methods Enzymol 314:136-148.

Charpak S, Gähwiler BH, Do KQ, Knöpfel T (1990) Potassium conductances in hippocampal neurons blocked by excitatory amino-acid transmitters. Nature 347:765-767.

Cole AE, Nicoll RA (1983) Acetylcholine mediates a slow synaptic potential in hippocampal pyramidal cells. Science 221:1299-1301.

Cole AE, Nicoll RA (1984) The pharmacology of cholinergic excitatory responses in hippocampal pyramidal cells. Brain Res 305:283-290.

Colino A, Halliwell JV (1993) Carbachol potentiates Q current and activates a calcium-dependent non-specific conductance in rat hippocampus in vitro. Eur J Neurosci 5:1198-1209.

Crepel V, Aniksztejn L, Ben-Ari Y, Hammond C (1994) Glutamate metabotropic receptors increase a $\mathrm{Ca}^{2+}$-activated nonspecific cationic current in CA1 hippocampal neurons. J Neurophysiol 72:1561-1569.

Dutar P, Nicoll RA (1988) Classification of muscarinic responses in hippocampus in terms of receptor subtypes and second-messenger systems: electrophysiological studies in vitro. J Neurosci 8:4214-4224.

Exton JH (1996) Regulation of phosphoinositide phospholipases by hormones, neurotransmitters, and other agonists linked to $G$ proteins. Annu Rev Pharmacol Toxicol 36:481-509.

Gerber U, Sim JA, Gähwiler BH (1992) Reduction of potassium conductances mediated by metabotropic glutamate receptors in rat CA3 pyramidal cells does not require protein kinase $\mathrm{C}$ or protein kinase $\mathrm{A}$. Eur J Neurosci 4:792-797.

Gereau RW, Conn PJ (1995) Roles of specific metabotropic glutamate receptor subtypes in regulation of hippocampal CA1 pyramidal cell excitability. J Neurophysiol 74:122-129.

Greene CC, Schwindt PC, Crill WE (1994) Properties and ionic mechanisms of a metabotropic glutamate receptor-mediated slow afterdepolarization in neocortical neurons. J Neurophysiol 72:693-704.

Greif GJ, Sodickson DL, Bean BP, Neer EJ, Mende U (2000) Altered regulation of potassium and calcium channels by $\mathrm{GABA}_{\mathrm{B}}$ and adenosine receptors in hippocampal neurons from mice lacking $\mathrm{G} \alpha_{\mathrm{o}}$. J Neurophysiol 83:1010-1018.

Guerineau NC, Gähwiler BH, Gerber U (1994) Reduction of resting K ${ }^{+}$ current by metabotropic glutamate and muscarinic receptors in rat CA3 cells: mediation by G-proteins. J Physiol (Lond) 474:27-33.

Guerineau NC, Bossu JL, Gähwiler BH, Gerber U (1995) Activation of a nonselective cationic conductance by metabotropic glutamatergic and muscarinic agonists in CA3 pyramidal neurons of the rat hippocampus. J Neurosci 15:4395-4407.

Haj-Dahmane S, Andrade R (1997) Calcium-activated cation nonselective current contributes to the fast afterdepolarization in rat prefrontal cortex neurons. J Neurophysiol 78:1983-1989.

Haj-Dahmane S, Andrade R (1999) Muscarinic receptors regulate two different calcium-dependent non-selective cation currents in rat prefrontal cortex. Eur J Neurosci 11:1973-1980.

Haley JE, Abogadie FC, Delmas P, Dayrell M, Vallis Y, Milligan G, Caulfield MP, Brown DA, Buckley NJ (1998) The $\alpha$ subunit of $\mathrm{G}_{\mathrm{q}}$ contributes to muscarinic inhibition of the M-type potassium current in sympathetic neurons. J Neurosci 18:4521-4531.

Haley JE, Delmas P, Offermanns S, Abogadie FC, Simon MI, Buckley NJ, Brown DA (2000) Muscarinic inhibition of calcium current and M current in $\mathrm{G} \alpha_{\mathrm{q}}$-deficient mice. J Neurosci 20:3973-3979.

Halliwell JV, Adams PR (1982) Voltage-clamp analysis of muscarinic excitation in hippocampal neurons. Brain Res 250:71-92.
Hamilton SE, Loose MD, Qi M, Levey AI, Hille B, McKnight GS, Odzerda RL, Nathanson NM (1997) Disruption of the $m 1$ receptor gene ablates muscarinic receptor-dependent $\mathrm{M}$ current regulation and seizure activity in mice. Proc Natl Acad Sci USA 94:13311-13316.

Heuss C, Scanziani M, Gähwiler BH, Gerber U (1999) G-proteinindependent signaling mediated by metabotropic glutamate receptors. Nat Neurosci 2:1070-1077.

Hille B (1994) Modulation of ion-channel function by G-protein-coupled receptors. Trends Neurosci 17:531-536.

Holscher C, Gigg J, O'Mara SM (1999) Metabotropic glutamate receptor activation and blockade: their role in long-term potentiation, learning and neurotoxicity. Neurosci Biobehav Rev 23:399-410.

Ikeda SR (1997) Heterologous expression of receptors and signaling proteins in adult mammalian sympathetic neurons by microinjection. Methods Mol Biol 83:191-202

Kleppisch T, Allmann R, Voigt V, Offermanns S (2001) G $\alpha$-deficient mice lack mGluR-dependent LTD but show normal LTP in the hippocampal CA1 region. J Neurosci 21:4943-4948.

Krause M, Pedarzani P (1999) Suppression of the $\mathrm{Ca}^{2+}$-activated $\mathrm{K}^{+}$ current $\mathrm{sI}_{\mathrm{AHP}}$ by cholinergic and glutamatergic agonists involves a protein phosphatase and PKG in hippocampal neurons. In: Proceedings of the 1st Göttingen Conference of the German Neuroscience Society, p 702. Stuttgart: Verlag.

Krause M, Pedarzani P (2000) A protein phosphatase is involved in the cholinergic suppression of the $\mathrm{Ca}^{2+}$-activated $\mathrm{K}^{+}$current $\mathrm{sI}_{\mathrm{AHP}}$ in hippocampal pyramidal neurons. Neuropharmacology 39:1274-1283.

Lei Q, Talley EM, Bayliss DA (2001) Receptor-mediated inhibition of G protein-coupled inwardly rectifying potassium channels involves $\mathrm{G} \alpha_{\mathrm{q}}$ family subunits, phospholipase $\mathrm{C}$, and a readily diffusible messenger. J Biol Chem 276:16720-16730.

Madison DV, Lancaster B, Nicoll RA (1987) Voltage-clamp analysis of cholinergic action in the hippocampus. J Neurosci 7:733-741.

Mailleux P, Mitchell F, Vanderhaeghen JJ, Milligan G, Erneux C (1992) Immunohistochemical distribution of neurons containing the G-proteins Gq alpha/G11 alpha in the adult rat brain. Neuroscience $51: 311-316$

McCormick DA, von Krosigk M (1992) Corticothalamic activation modulates thalamic firing through glutamate metabotropic receptors. Proc Natl Acad Sci USA 89:2774-2778.

McCormick DA, Williamson A (1989) Convergence and divergence of neurotransmitter action in human cerebral cortex. Proc Natl Acad Sci USA 86:8098-8102.

McFadzean I, Caulfield MP, Vallis Y, Brown DA (1994) Injection of antisera into cells to study G-protein regulation of channel function. Methods Enzymol 238:357-364.

Milligan G (1993) Regional distribution and quantitative measurement of the phosphoinositidase $\mathrm{C}$-linked guanine nucleotide binding proteins G11 alpha and Gq alpha in rat brain. J Neurochem 61:845-851.

Müller W, Petrozzino JJ, Griffith LC, Danho W, Connor JA (1992) Specific involvement of $\mathrm{Ca}^{2+}$-calmodulin kinase II in cholinergic modulation of neuronal responsiveness. J Neurophysiol 68:2264-2269.

Nicoll RA (1988) The coupling of neurotransmitter receptors to ion channels in the brain. Science 241:545-551.

Offermanns S (1999) New insights into the in vivo function of heterotrimeric G-proteins through gene deletion studies. Naunyn Schmiedebergs Arch Pharmacol 360:5-13.

Offermanns S, Heiler E, Spicher K, Schultz G (1994) Gq and G11 are concurrently activated by bombesin and vasopressin in Swiss 3T3 cells. FEBS Lett 349:201-204.

Offermanns S, Hashimoto K, Watanabe M, Sun W, Kurihara H, Thompson RF, Inoue Y, Kano M, Simon MI (1997) Impaired motor coordination and persistent multiple climbing fiber innervation of cerebellar Purkinje cells in mice lacking $\mathrm{G} \alpha_{\mathrm{q}}$. Proc Natl Acad Sci USA 94:14089-14094.

Offermanns S, Zhao LP, Gohla A, Sarosi I, Simon MI, Wilkie TM (1998) Embryonic cardiomyocyte hypoplasia and craniofacial defects in $\mathrm{G} \alpha_{\mathrm{q}} / \mathrm{G} \alpha_{11}$-mutant mice. EMBO J 17:4304-4312.

Pedarzani P, Storm JF (1993) PKA mediates the effects of monoamine transmitters on the $\mathrm{K}^{+}$current underlying the slow spike frequency adaptation in hippocampal neurons. Neuron 11:1023-1035.

Pedarzani P, Storm JF (1995) Dopamine modulates the slow $\mathrm{Ca}^{2+}$. activated $\mathrm{K}^{+}$current $\mathrm{I}_{\mathrm{AHP}}$ via cyclic AMP-dependent protein kinase in hippocampal neurons. J Neurophysiol 74:2749-2753.

Pedarzani P, Storm JF (1996) Evidence that Ca/calmodulin-dependent protein kinase mediates the modulation of the $\mathrm{Ca}^{2+}$-dependent $\mathrm{K}^{+}$ current, $\mathrm{I}_{\mathrm{AHP}}$, by acetylcholine, but not by glutamate, in hippocampal neurons. Pflügers Arch 431:723-728.

Perry E, Walker M, Grace J, Perry R (1999) Acetylcholine in mind: a neurotransmitter correlate of consciousness? Trends Neurosci 22:273-280.

Pin JP, Bockaert J (1995) Get receptive to metabotropic glutamate receptors. Curr Opin Neurobiol 5:342-349.

Pitler TA, Alger BE (1990) Activation of the pharmacologically defined 
M3 muscarinic receptor depolarizes hippocampal pyramidal cells. Brain Res 534:257-262.

Riedel G (1996) Function of metabotropic glutamate receptors in learning and memory. Trends Neurosci 19:219-224.

Rouse ST, Hamilton SE, Potter LT, Nathanson NM, Conn PJ (2000) Muscarinic-induced modulation of potassium conductances is unchanged in mouse hippocampal pyramidal cells that lack functional M1 receptors. Neurosci Lett 278:61-64.

Segal M, Auerbach JM (1997) Muscarinic receptors involved in hippocampal plasticity. Life Sci 60:1085-1091.

Stocker M, Krause M, Pedarzani P (1999) An apamin-sensitive $\mathrm{Ca}^{2+}$. activated $\mathrm{K}^{+}$current in hippocampal pyramidal neurons. Proc Natl Acad Sci USA 96:4662-4667.

Tanaka J, Nakagawa S, Kushiya E, Yamasaki M, Fukaya M, Iwanaga T, Simon MI, Sakimura K, Kano M, Watanabe M (2000) Gq protein $\alpha$ subunits $\mathrm{G} \alpha_{\mathrm{q}}$ and $\mathrm{G} \alpha_{11}$ are localized at postsynaptic extra-junctional membrane of cerebellar Purkinje cells and hippocampal pyramida cells. Eur J Neurosci 12:781-792

Wange RL, Smrcka AV, Sternweis PC, Exton JH (1991) Photoaffinity labeling of two rat liver plasma membrane proteins with $\left.{ }^{32} \mathrm{P}\right]$ gammaazidoanilido GTP in response to vasopressin. Immunologic identification as $\alpha$ subunits of the $\mathrm{Gq}$ class of $\mathrm{G}$ proteins. J Biol Chem 266:11409-11412.

Wu D, Katz A, Lee CH, Simon MI (1992) Activation of phospholipase C by $\alpha_{1}$-adrenergic receptors is mediated by the $\alpha$ subunits of $\mathrm{Gq}$ family. J Biol Chem 267:25798-25802.

Wu RL, Barish ME (1999) Modulation of a slowly inactivating potassium current, $I_{\mathrm{D}}$, by metabotropic glutamate receptor activation in cultured hippocampal pyramidal neurons. J Neurosci 19:6825-6837.

Zhang L, Weiner JL, Carlen PL (1992) Muscarinic potentiation of $I_{K}$ in hippocampal neurons: electrophysiological characterization of the signal transduction pathway. J Neurosci 12:4510-4520. 